\title{
PERSISTENT ORGANIC POLLUTANTS IN LITHUANIA: ASSESSMENT OF AIR AND SOIL CONTAMINATION
}

\author{
A. Milukaitè ${ }^{\text {a }}$ J. Klánová ${ }^{\mathrm{b}}$, I. Holoubek ${ }^{\mathrm{b}}$, I. Rimšelytė ${ }^{\mathrm{a}}$, and K. Kvietkus ${ }^{\text {a }}$ \\ ${ }^{a}$ Institute of Physics, Savanoriu 231, LT-02300 Vilnius, Lithuania \\ E-mail: amk@ktl.mii.lt \\ ${ }^{\mathrm{b}}$ Research Centre for Environmental Chemistry and Ecotoxicology of Masaryk University, Kamenice 126/3, CZ-62500 Brno, \\ Czech Republic
}

Received 8 September 2008; revised 14 November 2008; accepted 4 December 2008

\begin{abstract}
Persistent organic pollutants (POPs) such as polycyclic aromatic hydrocarbons (PAHs), polychlorbiphenyls (PCBs), and pesticides (hexachlorcyclohexanes (HCHs), dichlordiphenyltrichlormetilmetanes (DDTs)) were investigated in the atmospheric air and soil at 5 sites of Lithuania during March-August, 2006. POPs concentration at different sampling sites varied in the range of $6.39-127.8 \mathrm{ng} \mathrm{m}^{-3}, 0.017-0.440 \mathrm{ng} \mathrm{m}^{-3}, 0.088-0.310 \mathrm{ng} \mathrm{m}^{-3}$, and $0.006-0.360 \mathrm{ng} \mathrm{m}^{-3}$ in the atmospheric air and in the range of 29.5-529.3 $\mathrm{ng} \mathrm{g}^{-1}, 0.6-24.0 \mathrm{ng} \mathrm{g}^{-1}, 0.4-1.1 \mathrm{ng} \mathrm{g}^{-1}$, and $0.3-7.7 \mathrm{ng} \mathrm{g}^{-1}$ in soil for PAHs, PCBs, HCHs, and DDTs, respectively. The direct relationship between the POPs concentration level in the atmospheric air and soil at all sampling sites was observed. The concentrations of PAHs dominated over those of other POP groups in the atmospheric air and soil as well. The highest concentrations of almost all POP compounds were determined in the atmospheric air and soil in Vilnius city at the site with intensive traffic and commercial activity. Such wide range investigations of POPs in the natural environment components have been performed for the first time in Lithuania.
\end{abstract}

Keywords: PAHs, PCBs, HCHs, DDTs, concentration, passive samplers, atmospheric air, soil

PACS: 82.33.Tb; 92.60.Mt; 07.88.+y

\section{Introduction}

Persistent organic pollutants (POPs) due to their wide distribution, ability to bioaccumulate in the fatty tissue, and carcinogen, mutagen, or endocrine disruption potential remain in the centre of researchers' attention [1]. Among different organic matters, POPs (polycyclic aromatic hydrocarbons (PAHs), polychlorinated biphenyls (PCBs), pesticides, polychlorinated dibenzo$p$-dioxins, and dibenzofurans) are the most interesting from the point of view of their behaviour in the environment. Different classes of POPs are emitted from various sources: PAHs are mainly emitted in combustion processes from industrial or domestic sites and traffic [2], PCBs are spread via chemicals used in semiconductor industry and by waste disposal $[3,4]$, dibenzo$p$-dioxins and dibenzofurans via operation of landfills and incinerations $[5,6]$, and pesticides are spread via dispersion to the soil $[7,8]$. Furthermore, secondary sources of POPs include the spreading of sludge on the ground surface and remobilization of previously deposited compounds from soil and water bodies. The atmosphere often plays a key role in their transport within the immediate vicinity of POP sources as well as over great distances $[9,10]$. Atmospheric transport is also the main route for carrying POPs to the terrestrial and aquatic ecosystems $[11,12]$.

Research on POPs in the environment currently focuses on determination of uncertainties due to their ambient sources, atmospheric transport and fate, and airsurface exchange to clarify the complex factors controlling air concentrations. Measurements of the atmospheric air concentration at different sites are needed to assess contribution of sources, atmospheric processes, and the long-range atmospheric transport of potential toxic POPs.

High-volume samplers are usually used as conventional sampling techniques to determine POPs in the atmospheric air $[6,7,13-15]$. The relatively high cost of the equipment as well as the requirement for a pump and source of electricity are important disadvantages of this sampling method. A potential alternative is the use of passive samplers. These devices can be deployed at many sites at the same time, which offers a new approach to the large-scale investigation. As it provides information about long-term contamination of 
the selected site, passive air sampling can be used as a screening method for semi-quantitative comparison of different sites having advantage of low sensitivity to accidental short-time changes in the concentration of pollutants. However, it has been demonstrated that passive air samplers are mainly available for study of vapourphase POPs, they are applied to POP monitoring on the global and regional scale [16-18].

The aim of this study was to determine some polycyclic aromatic hydrocarbons, polychlorinated biphenyls, and pesticides by exposing passive samplers in the territory of Lithuania according to the program of the pilot study for development of the monitoring network in the Central and Eastern Europe (MONET CEEC), 2006 under the auspices of Research Centre for Environmental Chemistry and Ecotoxicology (RECETOX), Masaryk University, Brno, Czech Republic. Furthermore, this study was the first attempt to investigate the distribution of POPs such as PCBs and organic chlorinated pesticides in the environment of Lithuania.

\section{Experiment write-up}

Sampling sites. Monthly sampling of POPs in the atmospheric air was performed at 5 chosen sites in the territory of Lithuania in the period of 21 March to 13 August 2006: two sampling sites were chosen in the western part (Preila, Plateliai) and three sampling sites in the eastern part of Lithuania (Vilnius, Aukštieji Paneriai, Rūgšteliškis) (Fig. 1). The selected sites comprised commercial and industrial part of the Vilnius city and its suburb Aukštieji Paneriai, while other sites represented the monitoring background stations. Detailed characteristics of the sampling sites are presented below:

- Preila $\left(55^{\circ} 20^{\prime} \mathrm{N} ; 21^{\circ} 00^{\prime} \mathrm{E}\right)$ is a background environmental pollution research station of the Institute of Physics (Lithuania) on the southeastern coast of the Baltic Sea. It is located on the Curonian Spit (70 km in length and $2-3 \mathrm{~km}$ in width) separating the Curonian Lagoon from the Baltic Sea. The main local sources of pollution are small villages situated along the spit and the traffic on the road KlaipedaKaliningrad at a distance of $300 \mathrm{~m}$.

- Plateliai $\left(56^{\circ} 00^{\prime} 62^{\prime \prime} \mathrm{N} ; 21^{\circ} 52^{\prime} 28^{\prime \prime} \mathrm{E}\right)$ is an integrated monitoring station located in Žemaitija national park, $50 \mathrm{~km}$ to the east from the Baltic Sea.

- Rūgšteliškis $\left(55^{\circ} 26^{\prime} 26^{\prime \prime} \mathrm{N} ; 26^{\circ} 03^{\prime} 60^{\prime \prime} \mathrm{E}\right)$ is an integrated monitoring station located in the Aukštaitija National Park where measurements of POPs according to EMEP project are performed.

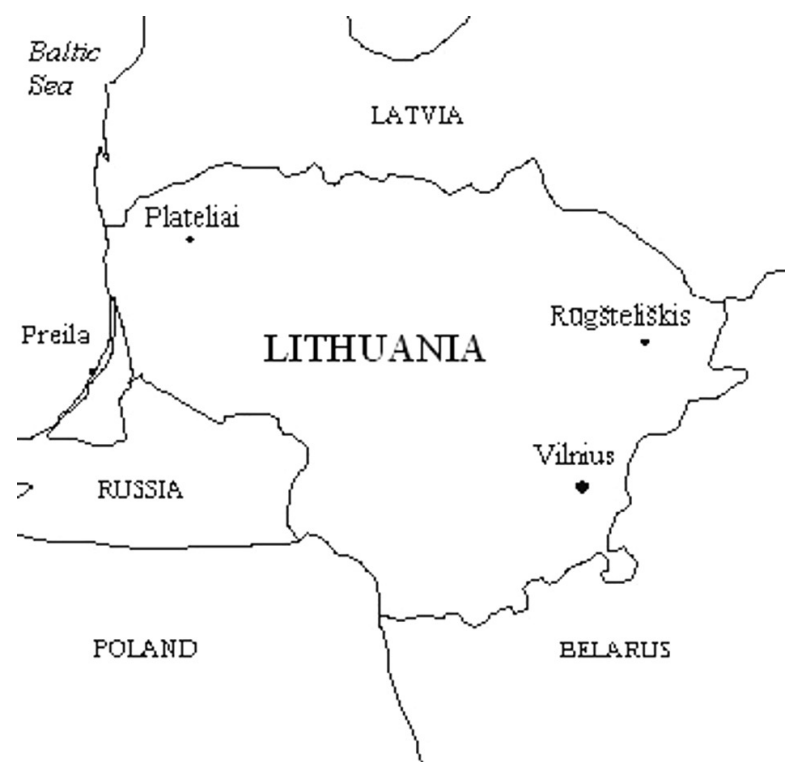

Fig. 1. Geographical location of sampling sites.

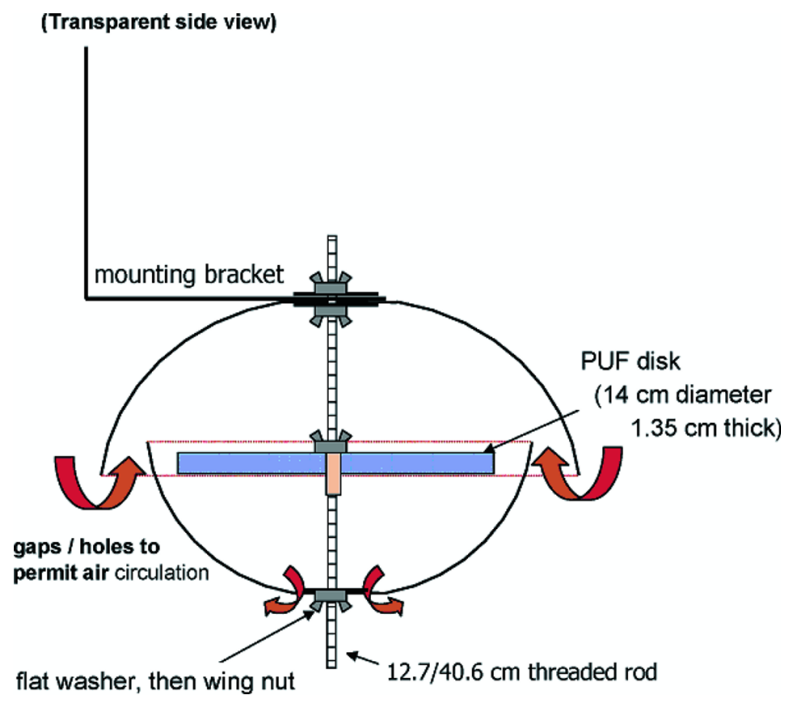

Fig. 2. Scheme of the passive air sampling device.

- Aukštieji Paneriai sampling site $\left(54^{\circ} 39^{\prime} 30^{\prime \prime} \mathrm{N} ; 25^{\circ}\right.$ $14^{\prime} 16^{\prime \prime} \mathrm{E}$ ) is in the forested area, in the territory of the Institute of Physics in the southwestern part of Vilnius city. Experimental waste and local traffic can be a source of pollution.

- Vilnius sampling site $\left(54^{\circ} 42^{\prime} 37^{\prime \prime} \mathrm{N} ; 25^{\circ} 20^{\prime} 40^{\prime \prime} \mathrm{E}\right)$ is located in the commercial and industrial part of Vilnius city near the street with intensive traffic (Žemaitès $\mathrm{St}$ ), among residential buildings.

Concentrations of POPs in the soil at air sampling sites were determined as well. The plot of about 10$15 \mathrm{~m}^{2}$ area without vegetation cover in each location was selected. From 5 to 10 subsamples (ca $0.3-0.5 \mathrm{~kg}$ ) were taken at different random points from the soil sur- 
face layer $(0-10 \mathrm{~cm})$ of this area. Five combined samples of soil were collected at all air sampling sites at the end of air sampling campaign (August, 2006).

Sampling. For sampling of POPs in the atmospheric air, passive air samplers were used. They are composed of a foam disk $(15 \mathrm{~cm}$ diameter, $1.5 \mathrm{~cm}$ thick, $0.03 \mathrm{~g} \mathrm{~m}^{-3}$ density, type N 3038, Gumotex Breclav, Czech Republic) placed in a stainless steel sampling chamber consisting of two domes (Fig. 2) [19]. This "flying saucer" design protects the foam disks from direct precipitation, sunlight, and coarse particle deposition.

Sampling chambers were prewashed and solventrinsed with acetone prior to installation. All filters were prewashed, cleaned (8-hour-extraction in acetone and 8-hour-extraction in dichloromethane), wrapped in two layers of aluminum foil, placed into zip-lock polyethylene bags, and kept in the freezer prior to deployment. Exposed filters were wrapped in two layers of aluminum foil, labelled, placed into zip-lock polyethylene bags, and transported in a cooler at $5^{\circ} \mathrm{C}$ to the laboratory where they were kept in the freezer at $-18{ }^{\circ} \mathrm{C}$ until the analysis. Air was allowed to flow over the sampling surface through a $\sim 2.5 \mathrm{~cm}$ gap between two domes. The average sampling rate was estimated to be $3.5 \mathrm{~m}^{3}$ /day, which roughly corresponds to $100 \mathrm{~m}^{3}$ for a 28-day sampling cycle. Exposure time of four to twelve weeks enables determination of many compounds from the POP group [20]. The technique of passive sampling and uptake of POPs by polyurethane foam is described in $[16,21]$ and it was shown that passive samplers with polyurethane foam can be used mainly for gas phase POPs and may collect only some part of fine particles [18].

Analysis. All samples were extracted with dichlormethane in a Büchi system B-811 automatic extractor. Surrogate recovery standards (d8-naphtalene, d10phenantrene, d12-perylene for PAH analysis, PCB 30 and PCB 185 for PCB analysis) were spiked on each filter prior to extraction. Terphenyl was used as internal standard for polyaromatic hydrocarbons (PAHs) and PCB 121 was used for polychlorinated biphenyl (PCB) / organochlorine pesticide (OCP) analyses. Volume of extracts after extraction was reduced under a gentle nitrogen stream at ambient temperature. Fractionation of PCB / OCP in extracts was performed on a silica gel column (a sulphuric acid modified silica gel). Samples were analysed using GC-ECD (HP 5890) supplied with a Quadrex fused silica column for PCBs such as PCB28, PCB52, PCB101, PCB118, PCB153, PCB138, PCB180, and OCPs such as $\alpha$-hexachloro- cyclohexane $(\mathrm{HCH}), \beta-\mathrm{HCH}, \gamma-\mathrm{HCH}, \delta-\mathrm{HCH}, 1,1-$ dichloro-2,2-bis ( $p$-chlorphenyl)ethylene ( $p, p^{\prime}$-DDE), 1,1-dichloro-2,2-bis ( $p$-chloroprene) ethan ( $p, p^{\prime}$ DDD), 1,1,1-trichloro-2,2-bis ( $p$-chloroprene) ethan ( $p, p^{\prime}$-DDT), $o, p^{\prime}$-DDE, $o, p^{\prime}$-DDD, hexachlorobenzene $(\mathrm{HCB})$, and pentachlorobenzene (PeCB). Furthermore, 16 polycyclic aromatic hydrocarbons recommended by EPA (Environmental protection agency, USA) were determined in all samples using the GC-MS instrument (HP 6890 - HP 5972) supplied with a J\&W scientific fused silica column DB-5MS. The laboratory blank test and the reference material were analysed with each set of ten samples. Limit of quantification was $0.2 \mathrm{ng}$ filter ${ }^{-1}\left(=2 \mathrm{pg} \mathrm{m}^{-3}\right)$ [22].

Meteorological data such as ambient temperature, precipitation, humidity, and wind speed direction for all sampling sites during each period of investigation have been taken from the NOAA (National Oceanic and Atmospheric Administration) meteorological network [23].

\section{Results and discussion}

The ranges and averages of monthly concentrations of various POPs in the atmospheric air at five monitoring sites of Lithuania are presented in Table 1 and distribution of sum of concentrations of each group of determined pollutants at different sites is presented in Fig. 3. Data indicate that concentrations of various POPs are different in the territory of Lithuania with wide variation of some pollutants. The concentrations of PAHs profiles showed that 2-3-ringed (from naphthalene to antracene) and 4-ringed (fluoranthene and pyrene) of PAH species were higher than those of 5- and 6-ringed PAHs, which, according to earlier studies, were mainly associated with particles in the atmospheric air [14]. A decreasing trend from March to August was observed for each of 16 PAHs at all sampling sites clearly indicating seasonality of pollution and suggesting generation of PAHs by fuel burning for domestic heating in the period of March-April. Furthermore, the concentrations of lighter PAHs determined in this study were very similar to those determined at the Preila background station in 1991 by using low volume air filtration, while the concentrations of particulate PAHs determined by the method of passive samplers were relatively low compared with those determined earlier at the background sites [24] and Vilnius city or its suburb as well [25]. It may be explained by the possibility of passive samplers to adsorb more vapour than particulate phase POPs. However, the concentrations determined for particulate 

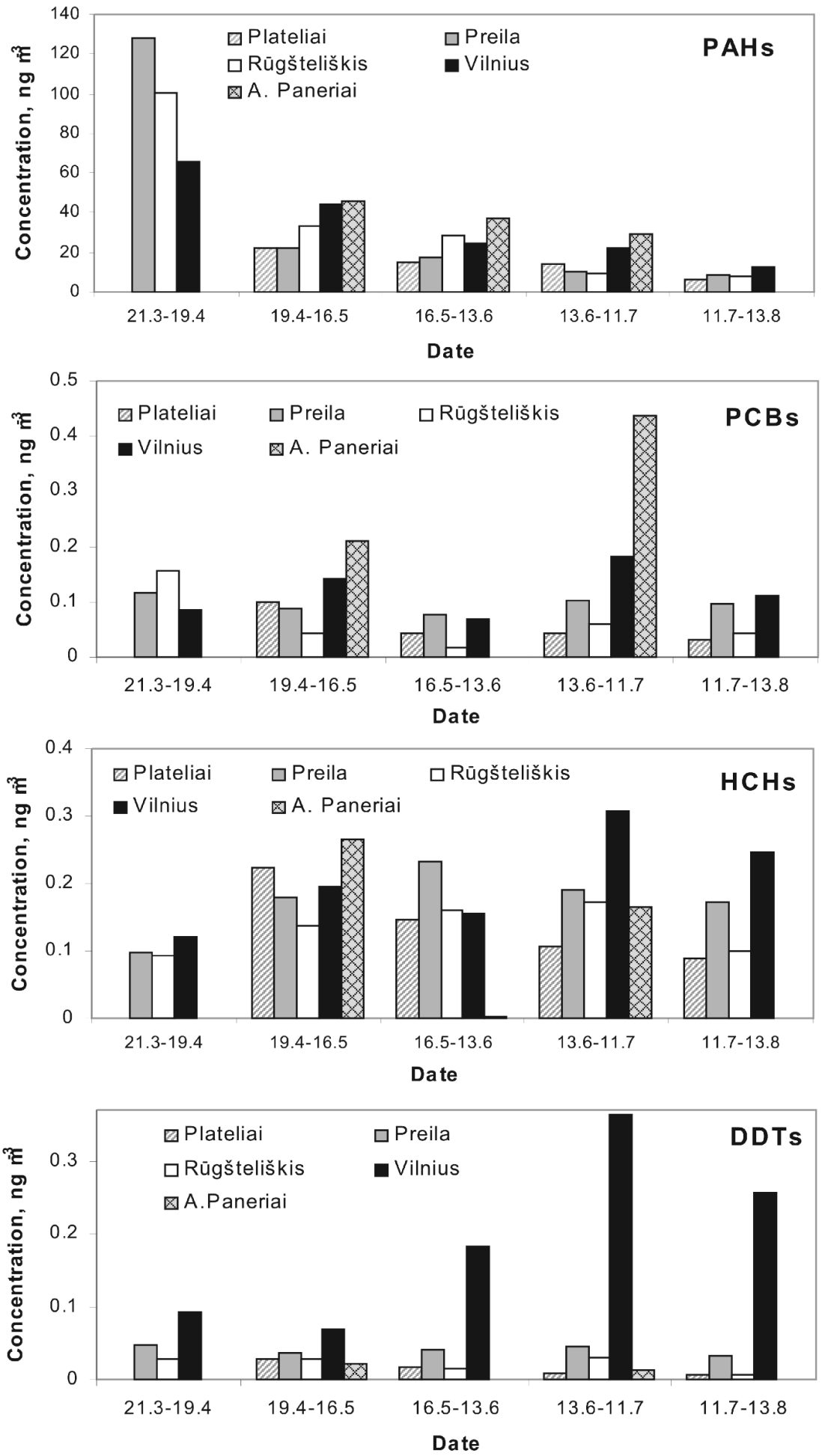

Fig. 3. Changes in sum of concentrations of each POP group in the atmospheric air at different sampling sites. 
Table 1. Ranges and averages of POP concentrations in the atmospheric air $\left(\mathrm{ng} \mathrm{m}^{-3}\right)$ at the sampling sites ( 5 sampling periods for each site, STD means standard deviation, DL is detection limit).

\begin{tabular}{|c|c|c|c|c|c|}
\hline POPs & Minimum & Maximum & Average & STD & Variance, $\%$ \\
\hline \multicolumn{6}{|l|}{ PAHs } \\
\hline Naphthalene & 1.71 & 48.7 & 13.2 & 11.6 & 88.0 \\
\hline Acenaphththylene & 0.04 & 3.26 & 0.78 & 0.95 & 120.8 \\
\hline Acenaphthene & 0.11 & 2.42 & 0.58 & 0.61 & 104.8 \\
\hline Fluorene & 0.32 & 21.3 & 3.46 & 5.15 & 148.9 \\
\hline Phenanthrene & 1.07 & 43.4 & 9.73 & 10.6 & 108.9 \\
\hline Anthracene & 0.02 & 4.86 & 0.43 & 1.02 & 235.7 \\
\hline Fluoranthene & 0.41 & 12.6 & 2.27 & 2.62 & 115.4 \\
\hline Pyrene & 0.22 & 4.16 & 1.28 & 0.93 & 72.8 \\
\hline Benz(a)anthracene & 0.00 & 0.09 & 0.03 & 0.02 & 75.9 \\
\hline Chrysene & 0.00 & 0.48 & 0.08 & 0.10 & 122.8 \\
\hline Benzo(b)fluoranthene & 0.01 & 0.09 & 0.04 & 0.02 & 45.6 \\
\hline Benzo(k)fluoranthene & 0.01 & 0.05 & 0.02 & 0.01 & 47.9 \\
\hline Benzo(a)pyrene & 0.01 & 0.05 & 0.03 & 0.01 & 40.5 \\
\hline Indeno( $(1,2,3, \mathrm{c}, \mathrm{d})$ pyrene & $<\mathrm{DL}$ & 0.05 & 0.03 & 0.01 & 50.0 \\
\hline Dibenz(a,h)anthracene & $<\mathrm{DL}$ & $<\mathrm{DL}$ & $<\mathrm{DL}$ & $<\mathrm{DL}$ & - \\
\hline Benzo(g,h,i)perylene & 0.00 & 0.10 & 0.06 & 0.02 & 34.2 \\
\hline Sum of PAHs & 6.4 & 127.8 & 32.1 & 30.6 & 95.3 \\
\hline \multicolumn{6}{|l|}{ PCBs } \\
\hline PCB 28 & 0.008 & 0.265 & 0.039 & 0.054 & 138.7 \\
\hline РCB 52 & 0.006 & 0.087 & 0.027 & 0.019 & 70.6 \\
\hline PCB 101 & $<\mathrm{DL}$ & 0.036 & 0.016 & 0.009 & 66.6 \\
\hline PCB 118 & $<\mathrm{DL}$ & 0.024 & 0.013 & 0.006 & 48.0 \\
\hline PCB 153 & $<\mathrm{DL}$ & 0.022 & 0.010 & 0.006 & 62.0 \\
\hline PCB 138 & $<\mathrm{DL}$ & 0.013 & 0.006 & 0.003 & 42.3 \\
\hline PCB 180 & $<\mathrm{DL}$ & 0.029 & 0.006 & 0.007 & 101.1 \\
\hline Sum of PCBs & 0.017 & 0.440 & 0.100 & 0.090 & 81.7 \\
\hline \multicolumn{6}{|l|}{ HCHs } \\
\hline$\alpha-\mathrm{HCH}$ & 0.011 & 0.203 & 0.077 & 0.044 & 57.3 \\
\hline$\beta-\mathrm{HCH}$ & $<\mathrm{DL}$ & 0.042 & 0.022 & 0.011 & 49.6 \\
\hline$\gamma-\mathrm{HCH}$ & 0.027 & 0.147 & 0.071 & 0.029 & 41.3 \\
\hline$\delta-\mathrm{HCH}$ & $<\mathrm{DL}$ & $<\mathrm{DL}$ & $<\mathrm{DL}$ & $<\mathrm{DL}$ & - \\
\hline Sum of HCHs & 0.088 & 0.310 & 0.166 & 0.060 & 36.2 \\
\hline \multicolumn{6}{|l|}{ DDTs } \\
\hline$o, p$-DDE & $<\mathrm{DL}$ & 0.013 & 0.012 & 0.002 & 13.1 \\
\hline$p, p '-\mathrm{DDE}$ & 0.006 & 0.151 & 0.034 & 0.036 & 103.3 \\
\hline$o, p^{\prime}-\mathrm{DDD}$ & $<\mathrm{DL}$ & 0.027 & 0.013 & 0.012 & 91.7 \\
\hline$p, p '-\mathrm{DDD}$ & 0.000 & 0.039 & 0.010 & 0.012 & 118.8 \\
\hline$o, p$-DDT & $<\mathrm{DL}$ & 0.065 & 0.022 & 0.024 & 109.4 \\
\hline$p, p '-\mathrm{DDT}$ & $<\mathrm{DL}$ & 0.083 & 0.023 & 0.027 & 117.8 \\
\hline Sum of DDTs & 0.006 & 0.360 & 0.063 & 0.090 & 144.3 \\
\hline
\end{tabular}

PAHs were in the interval of monthly concentrations earlier determined at these sites. Long-term investigation of benzo(a)pyrene showed that its monthly concentration in the atmospheric air varied from 0.02 to $1.72 \mathrm{ng} \mathrm{m}^{-3}$ with high frequency of daily concentrations of $0.02-0.50 \mathrm{ng} \mathrm{m}^{-3}$ at the Preila background station in warm season (May-September) and from 0.18 to $3.30 \mathrm{ng} \mathrm{m}^{-3}$ with high frequency of $0.20-1.00 \mathrm{ng} \mathrm{m}^{-3}$ daily concentration in cold season (October-April) during 1980-2002 [26].
The highest concentrations of PCBs were obtained at the background sites in springtime (March-April period), while at urban sites, Vilnius city and its suburb Aukštieji Paneriai, they were higher in summertime. The analysis of synoptic situation shows that in the period from 25 March to 19 April the territory of Lithuania was under the influence of polluted SW air masses from industrial regions of Europe [27], while at the urban sites the local sources were dominating and concentrations of PCBs might increase with an increase of 
Table 2. Ranges and averages of POP concentrations in soil $\left(\mathrm{ng} \mathrm{g}^{-1}\right)$ at all sampling sites (STD means standard deviation, DL is detection limit).

\begin{tabular}{|c|c|c|c|c|c|}
\hline POPs & Minimum & Maximum & Average & STD & Variance, $\%$ \\
\hline \multicolumn{6}{|l|}{ PAHs } \\
\hline Naphthalene & 1.6 & 10.4 & 5.2 & 3.2 & 61.9 \\
\hline Acenaphththylene & 0.3 & 3.8 & 1.2 & 1.5 & 123.2 \\
\hline Acenaphthene & 0.2 & 1.8 & 0.6 & 0.7 & 108.4 \\
\hline Fluorene & 0.3 & 3.0 & 1.2 & 1.0 & 83.5 \\
\hline Phenanthrene & 3.5 & 49.5 & 16.0 & 22.3 & 138.8 \\
\hline Anthracene & 0.2 & 9.0 & 2.4 & 3.7 & 156.5 \\
\hline Fluoranthene & 3.5 & 70.0 & 20.6 & 27.8 & 135.3 \\
\hline Pyrene & 2.4 & 61.3 & 17.9 & 24.5 & 136.8 \\
\hline Benz(a)anthracene & 0.9 & 38.4 & 10.7 & 15.7 & 146.1 \\
\hline Chrysene & 1.9 & 40.3 & 11.9 & 16.0 & 134.4 \\
\hline Benzo(b)fluoranthene & 2.4 & 74.2 & 21.1 & 29.9 & 142.0 \\
\hline Benzo(k)fluoranthene & 1.3 & 22.3 & 7.1 & 8.6 & 121.1 \\
\hline Benzo(a)pyrene & 2.1 & 49.8 & 14.7 & 19.9 & 134.9 \\
\hline Indeno $(1,2,3, \mathrm{c}, \mathrm{d})$ pyrene & 2.9 & 44.8 & 14.8 & 17.0 & 115.2 \\
\hline Dibenz(a,h)anthracene & 0.2 & 5.2 & 1.5 & 2.1 & 136.4 \\
\hline Benzo(g,h,i)perylene & 2.4 & 45.5 & 13.9 & 17.8 & 127.9 \\
\hline Sum of PAHs & 29.5 & 529.3 & 158.5 & 209.1 & 131.9 \\
\hline \multicolumn{6}{|l|}{ PCBs } \\
\hline PCB 28 & $<\mathrm{DL}$ & 0.20 & 0.15 & 0.07 & 47.1 \\
\hline PCB 52 & 0.10 & 0.50 & 0.20 & 0.17 & 86.6 \\
\hline PCB 101 & 0.10 & 2.60 & 0.68 & 1.08 & 158.2 \\
\hline PCB 118 & 0.10 & 1.50 & 0.46 & 0.61 & 131.9 \\
\hline PCB 153 & 0.20 & 9.40 & 2.20 & 4.03 & 183.1 \\
\hline PCB 138 & 0.10 & 4.30 & 1.04 & 1.82 & 175.4 \\
\hline PCB 180 & 0.10 & 5.50 & 1.60 & 2.61 & 162.8 \\
\hline Sum of PCBs & 0.60 & 24.0 & 5.94 & 10.1 & 170.3 \\
\hline \multicolumn{6}{|l|}{ HCHs } \\
\hline$\alpha-\mathrm{HCH}$ & 0.10 & 0.50 & 0.32 & 0.16 & 51.4 \\
\hline$\beta-\mathrm{HCH}$ & 0.10 & 0.30 & 0.24 & 0.09 & 37.3 \\
\hline$\gamma-\mathrm{HCH}$ & 0.10 & 0.40 & 0.27 & 0.15 & 63.2 \\
\hline$\delta$-HCH & $<\mathrm{DL}$ & $<\mathrm{DL}$ & $<\mathrm{DL}$ & $<\mathrm{DL}$ & - \\
\hline Sum of HCHs & 0.40 & 1.10 & 0.80 & 0.29 & 36.4 \\
\hline \multicolumn{6}{|l|}{ DDTs } \\
\hline$o, p^{\prime}-\mathrm{DDE}$ & $<\mathrm{DL}$ & $<\mathrm{DL}$ & $<\mathrm{DL}$ & $<\mathrm{DL}$ & - \\
\hline$p, p '-\mathrm{DDE}$ & 0.20 & 2.40 & 0.76 & 0.92 & 121.5 \\
\hline$o, p '-\mathrm{DDD}$ & $<\mathrm{DL}$ & 0.80 & 0.45 & 0.49 & 110.0 \\
\hline$p, p '-\mathrm{DDD}$ & 0.10 & 3.60 & 0.80 & 1.57 & 195.7 \\
\hline$o, p^{\prime}-\mathrm{DDT}$ & $<\mathrm{DL}$ & $<\mathrm{DL}$ & $<\mathrm{DL}$ & $<\mathrm{DL}$ & - \\
\hline$p, p '-\mathrm{DDT}$ & $<\mathrm{DL}$ & $<\mathrm{DL}$ & $<\mathrm{DL}$ & $<\mathrm{DL}$ & - \\
\hline Sum of DDTs & 0.30 & 7.70 & 1.92 & 3.23 & 168.5 \\
\hline
\end{tabular}

ambient temperature. The increase of PCB concentrations with an increase of ambient temperature in the majority of PCB studies was observed earlier $[9,28]$. Furthermore, the level of concentration increased going from PCBs with higher degree of chlorination (PCB 180) to PCB congeners with lower degree of chlorination (PCB 28) which can be related to increasing volatility of these pollutants. The lowest concentrations of PCBs at urban sites were determined in cold period of March-April, while the highest concentrations of PCBs with large amount of PCB 28 were measured at highest ambient temperature (average temperature varied from 19.2 to $20.6^{\circ} \mathrm{C}$ at different sampling sites) at all sampling sites during 13 June -11 July. The sum of concentrations of PCB 28, 52, 101, 118, 153, 138, and 180 congeners varied between $0.017 \mathrm{ng} \mathrm{m}^{-3}$ in Rūgšteliškis and $0.155 \mathrm{ng} \mathrm{m}^{-3}$ in Preila with the highest value of $0.440 \mathrm{ng} \mathrm{m}^{-3}$ in Vilnius suburb. Concentrations of PCBs at background Lithuanian sites were similar to 


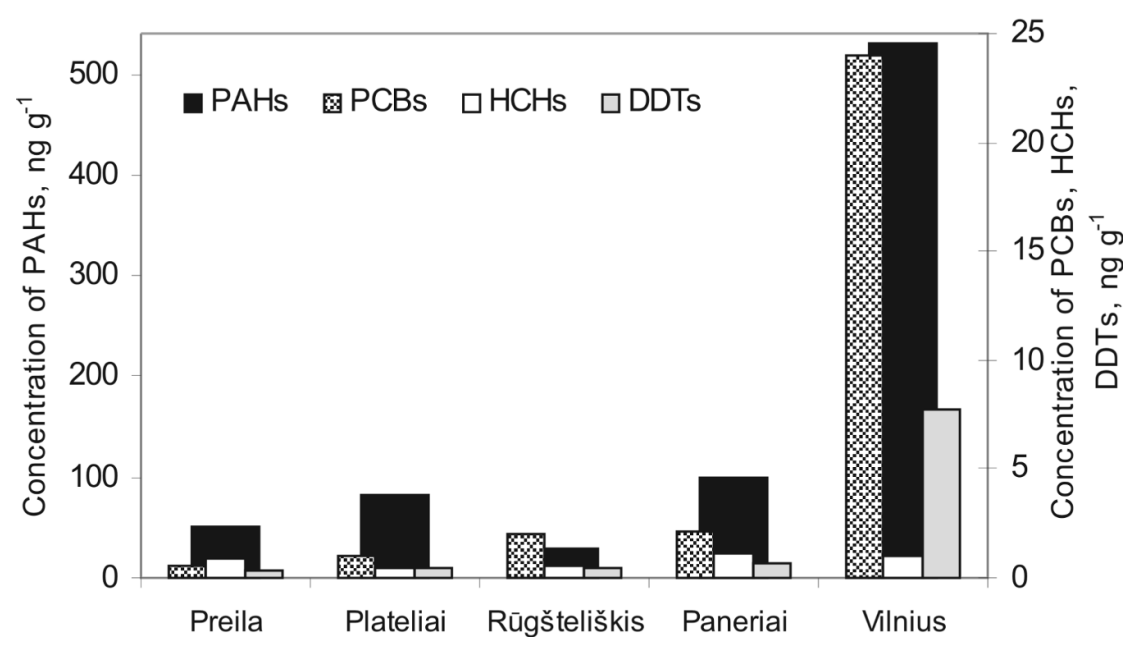

Fig. 4. Variation of concentrations of various POPs in soil at different sites.

those determined in UK, Wraymires rural site (from 12 to $230 \mathrm{pg} \mathrm{m}^{-3}$ ) in 1972-1992 [29].

The course of concentrations of different $\mathrm{HCH}$ isomers was similar at all sampling sites with higher concentrations from mid-April to August. Concentration of $\gamma-\mathrm{HCH}$ (the main component of lindane) was very similar to the $\alpha-\mathrm{HCH}$ pattern, but sometimes it was lower because $\gamma-\mathrm{HCH}$ may be transformed to $\alpha-\mathrm{HCH}$ due to photochemical reactions in the atmosphere [7]. In our study the sum of $\mathrm{HCH}$ concentrations varied from $0.088 \mathrm{ng} \mathrm{m}^{-3}$ in Plateliai to $0.310 \mathrm{ng} \mathrm{m}^{-3}$ in Vilnius. The highest sum of $\mathrm{HCHs}$ concentrations was observed from May to June with a decrease in August at all sampling sites. The level of $\alpha$-HCH concentration was relatively uniform at the background sites, while its level in Vilnius city was different.

Relatively high concentrations of DDTs, from 0.122 to $0.307 \mathrm{ng} \mathrm{m}^{-3}$, were determined in Vilnius city, but they ranged from 0.006 to $0.048 \mathrm{ng} \mathrm{m}^{-3}$ at the rural sites. The highest concentrations of pesticides $(\mathrm{HCHs}$ and DDTs) were observed in the period of their usage (April-June) and in the period of high atmospheric temperature during 13 June - 11 July. The lowest pollution by pesticides was determined at Plateliai and Rūgšteliškis integrated monitoring stations. Wide distribution of pesticides may be explained by their intensive application on local and global scales in the past and dispersion of these compounds over long distances through the atmosphere due to their relatively high volatility. As a result of their persistence, organochlorine residues were found in the air and precipitation after some decades $[8,9]$.

Distribution of different POPs in the soil depends on their deposition processes which are highly controlled by the physico-chemical properties of com- pounds (physical state, solubility, etc.) in the atmospheric air and meteorological conditions (ambient temperature, precipitation, etc.) [30]. Deposition of some heavier PCBs and high molecular weight PAHs is primarily caused by their insolubility. It was found that dry deposition of PAHs was larger than that of PCBs [14]. Particle deposition seems to be the major pathway of PAHs from the atmosphere to the ground surface, while the largest deposition of PCBs and $\mathrm{HCHs}$, due to their high water solubility, occurs by washout with precipitation. Furthermore, higher solubility of $\gamma-\mathrm{HCH}$ than of $\alpha-\mathrm{HCH}$ may affect the ratio $\alpha-\mathrm{HCH} / \gamma-\mathrm{HCH}$ in soil and air samples as well.

In our study, 5 combined samples of soil were analysed for the same POPs as in the atmospheric air of the sampling sites. Concentrations of 16 PAHs ranged from 29.5 to $99.1 \mathrm{ng} \mathrm{g}^{-1}$ at rural sites and with the highest value of $529.3 \mathrm{ng} \mathrm{g}^{-1}$ in the soil of Vilnius city (Table 2 and Fig. 4). Contrary to the atmospheric air, phenantrene, fluoranthene, and pyrene together with other high molecular weight particulate PAHs (5-6 rings) were dominating in soil. The dominance of particulate PAHs in the soil indicates that exchange of gaseous PAHs between the atmosphere and soil seems to be insignificant. High concentrations of PAHs in comparison with other POPs show that hydrophobic POPs compounds mainly tend to accumulate in the surface layer of soil.

The sum of PCB concentrations in the soil varied from 0.6 to $2.1 \mathrm{ng} \mathrm{g}^{-1}$ at background sites with the highest value of $24.0 \mathrm{ng} \mathrm{g}^{-1}$ at the site in the centre of Vilnius city. The concentrations of PCBs determined during this investigation were several times lower than those determined in England, ranging between 10 and $670 \mu \mathrm{g} \mathrm{kg}^{-1}$ (median $30 \mu \mathrm{g} \mathrm{kg}^{-1}$ ) [11]. 
The concentrations of HCHs and DDTs were found to be low and uniform in the soil of all rural areas, while concentrations of DDTs were exclusively elevated in the soil of Vilnius investigation site. The concentration of pesticides in Vilnius city was determined to be $1.0 \mathrm{ng} \mathrm{g}^{-1}$ and $7.7 \mathrm{ng} \mathrm{g}^{-1}$ for HCHs and DDTs, respectively. It is evident that the concentrations of all investigated POPs in the soil were by an order of magnitude higher in the urban soil. Furthermore, a relatively low variation of data showed that more uniform concentrations of all POPs were determined for $\mathrm{HCHs}$ at all investigated sites, which indicated stability of pollution sources compared with other POPs. The data presented in Figs. 3 and 4 showed a direct relationship of POP distribution between soil and the atmospheric air at all sampling sites. Consequently, the atmospheric air and soil were the cleanest at rural sampling sites (Plateliai, Rūgšteliškis, and Preila), except the period of MarchApril when the influence of heating season on the increase of PAH concentration level in the atmospheric air at the Preila background station was evident.

\section{Conclusions}

The sum of PAH, PCB, HCH, and DDT concentrations at 5 sampling sites in Lithuania varied in the range of $6.4-127.8 \mathrm{ng} \mathrm{m}^{-3}, 0.017-0.440 \mathrm{ng} \mathrm{m}^{-3}, 0.088-$ $0.310 \mathrm{ng} \mathrm{m}^{-3}$, and $0.006-0.360 \mathrm{ng} \mathrm{m}^{-3}$ in the atmospheric air and in the range of $29.5-529.3 \mathrm{ng} \mathrm{g}^{-1}, 0.6$ $24.0 \mathrm{ng} \mathrm{g}^{-1}, 0.4-1.1 \mathrm{ng} \mathrm{g}^{-1}$, and $0.3-7.7 \mathrm{ng} \mathrm{g}^{-1}$ in the soil, respectively. A direct relationship between POP level in the atmospheric air and soil at all sampling sites was determined. PAH concentrations dominated over the other POP groups in the atmospheric air and soil as well. The highest concentrations almost of all POP compounds were determined in the atmospheric air and soil in Vilnius city at the site with intensive traffic and commercial activity. The concentrations of PCBs, especially of their lower congeners (PCB 28), in the atmospheric air were higher in summertime during the period of higher ambient temperature. Contrary to other POP groups, concentrations of PAHs indicated a decreasing trend from spring months to the end of summertime. Comparison of the concentrations of benzo(a)pyrene determined by using passive samplers and low volume air filtration showed that concentrations of this particulate PAH were lower but they were in the interval of monthly variation determined earlier at the Preila background station by using the method of low volume air filtration.

\section{Acknowledgements}

This project was supported by Ministry of Education of the Czech Republic, Project MSM 0021622412 INCHEMBIOL, and Ministry of Environment of the Czech Republic, Project SP/1b1/30/07.

\section{References}

[1] K.S. Guruge and S. Tanabe, Contamination by persistent organochlorines and butyltin compounds in the west coast of Sri Lanka, Marine Pollution Bull. 2(3), 179-186 (2001).

[2] M.L. Lee, M.V. Novotny, and K.D. Bartle, Analytical Chemistry of Polycyclic Aromatic Compounds (Academic Press, 1981).

[3] C.J. Halsall, R.G.M. Lee, P.J. Colemman, V. Burnett, P. Harding-Jones, and K.C. Jones, PCBs in U.K. urban air, Environ. Sci. Technol. 29(9), 2368-2376 (1995).

[4] D.M. Wethington and K.C. Hombuckle, Milwaukee WI as a source of atmospheric PCBs to Lake Michigan, Environ. Sci. Technol. 39(1), 57-63 (2005).

[5] C.C. Travis, H.A. Hattemer-Frey, and E. Silbergeld, Dioxin, dioxin everywhere, Environ. Sci. Technol. 23(9), 1061-1063 (1989).

[6] M. Tysklind, I. Fangmark, S. Marklund, A. Lindskog, L. Thaning, and Ch. Rappe, Atmospheric transport and transformation of polychlorinated dibenzo-dioxins and dibenzofurans, Environ. Sci. Technol. 27(10), 21902197 (1993).

[7] M. Oehme, Further evidence for long-range air transport of polychlorinated aromates and pesticides: North America and Eurasia to the Arctic, Ambio 20(7), 293297 (1991).

[8] M. Millet, H. Wortham, A. Sanusi, and Ph. Mirabel, Atmospheric contamination by pesticides: Determination in the liquid, gaseous and particulate phases, Environ. Sci. Pollut. Res. 4(3), 172-180 (1997).

[9] Y.F. Li, T.F. Bidleman, L.A. Barrie, and L.L. McConnell, Global hexachlorcyclohexane use trends and their impact on the Arctic atmospheric environment, Geophys. Res. Lett. 25(1), 39-41 (1998).

[10] F. Wania, Assessing the potential of persistent organic chemicals for long-range transport and accumulation in polar regions, Environ. Sci. Technol. 37(7), 1344-1351 (2003).

[11] T. Harner, D. Mackay, and K.C. Jones, Model of the long-term exchange of PCBs between soil and the atmosphere in the southern UK, Environ. Sci. Technol. 29(5), 1200-1209 (1995).

[12] W.D. Hafner and R.A. Hites, Potential sources pesticides, PCBs, and PAHs to the atmosphere of the Great Lakes, Environ. Sci. Technol. 37(17), 3764-3773 (2003). 
[13] O. Roots and A. Sweetman, Passive air sampling of persistent organic pollutants in two Estonian air monitoring stations, Oil Shale 24(3), 483-494 (2007).

[14] E. Brorstrom-Lunden, A. Lindskog, and J. Mower, Concentrations and fluxes of organic compounds in the atmosphere of the Swedish west coast, Atmos. Environ. 28(22), 3605-3615 (1994).

[15] I. Holoubek, J. Klánová, J. Jarkovský, and J. Kohoutek, Trends in background levels of persistent organic pollutants at Kosetice observatory, Czech Republic, Part I. Ambient air and wet deposition 1988-2005, J. Environ. Monit. 9(6), 564-571 (2007).

[16] T. Harner, M. Shoeib, M. Diamond, G. Stern, and B. Rosenberg, Using passive air samplers to assess urban-rural trends for persistent organic pollutants. 1. Polychlorinated biphenyls and organochlorine pesticides, Environ. Sci. Technol. 38(17), 4474-4483 (2004).

[17] F. Jaward, N.J. Farrar, T. Harner, A. Sweetman, and K.C. Jones, Passive air sampling of PCBs, PBDEs, and organochlorine pesticides across Europe, Environ. Sci. Technol. 38(1), 34-41 (2004).

[18] T. Harner, K. Pozo, T. Gouin, A.M. Macdonald, H. Hung, J. Cainey, and A. Peters, Global pilot study of persistent organic pollutants (POPs) using PUF disk passive air samplers, Environ. Pollut. 144(2), 445-452 (2006).

[19] J. Klanova, P. Cupr, and I. Holoubek, Application of Passive Sampler for Monitoring of POPs in Ambient Air. Part II, RECETOX_TOCOEN Reports, 319 (Masaryk University, Brno, 2007).

[20] J. Kohoutek, I. Holoubek, and J. Klanova, Methodology of passive sampling, TOCOEN Report, 300 (Masaryk University, Brno, 2006) pp. 1-14.

[21] M. Shoeib and T. Harner, Characterization and comparison of three passive air samplers for persistent or- ganic pollutants, Environ. Sci. Technol. 36(19), 41424151 (2002).

[22] J. Klánová, J. Kohoutek, L. Hamplová, P. Urbanová, and J. Holoubek, Passsive air sampler as a tool for longterm air pollution monitoring, Part 1. Performance assessment for seasonal and special variations, Environ. Pollut. 144(2), 393-405 (2006).

[23] NOAA archive of the meteorological database: http:// www.arl.noaa.gov/ready/amet.html.

[24] A. Milukaite, A.K. Nika, and V.A. Yuozefaite, Relationships of distribution non-volatile organic compounds and carbon in atmospheric aerosol, J. Ecol. Chem. 1, 47-50 (1993).

[25] A. Milukaite and V. Morkunas, Variations in concentration of soot, total suspended particulates and organic admixtures in the air at the cross-roads, Environ. Chem. Phys. 21(3-4), 66-71 (1999).

[26] A. Milukaite, Long-term trends of benzo(a)pyrene concentration on the eastern coast of the Baltic Sea, Atmos. Environ. 40(11), 2046-2057 (2006).

[27] A. Milukaite and A. Mikelinskiene, Atmospheric air pollution regional background formation at the eastern coast of the Baltic Sea, in: Air Pollution Processes in Regional Scale, eds. D. Melas and D. Syrakov (Kluwer Academic Publishers, 2003) pp. 221-229.

[28] A. Alford-Stevens, Analysing PCBs, Environ. Sci. Technol. 20(12), 1194-1199 (1986).

[29] K.C. Jones, R. Duarte-Davidson, and P.A. Cause, Changes in the PCB concentration of United Kingdom air between 1972 and 1992, Environ. Sci. Technol. 29(1), 272-275 (1995).

[30] W. Tsal, Y. Cohen, H. Sakugawa, and I. Kaplan, Dynamic partitioning of semivolatile organics in gas / particle/ rain phases during rain scavening, Environ. Sci. Technol. 25(12), 2012-2023 (1991). 


\title{
PATVARŪS ORGANINIAI TERŠALAI LIETUVOJE: TARŠOS ORE IR DIRVOJE IVERTINIMAS
}

\author{
A. Milukaite ${ }^{\text {a }}$ J. Klánová ${ }^{b}$, I. Holoubek ${ }^{b}$, I. Rimšelytè ${ }^{a}$, K. Kvietkus ${ }^{a}$ \\ ${ }^{a}$ Fizikos institutas, Vilnius, Lietuva \\ ${ }^{\mathrm{b}}$ Masaryko Universitetas, Brno, Čekija
}

\section{Santrauka}

Patvarių organinių teršalų (POT), tame tarpe policiklinių aromatiniu angliavandeniliu (PAA), polichlorbifenilu (PCB) ir pesticidu (heksachlorcikloheksanu $(\mathrm{HCH})$, dichlordifeniltrichlormetilmetanu (DDT)), tyrimai atlikti $2006 \mathrm{~m}$. kovo-rugpjūčio mėnesiais atmosferos ore ir dirvoje penkiose Lietuvos vietovèse. POT atmosferos ore tirti panaudojant pasyvius sorbentus, kurie pastaruoju metu yra plačiai taikomi atmosferos užterštumo tyrimams regioniniu ir globaliu mastu. Tyrimų rezultatai parodè, kad 16-kos PAA junginių, 7-ių PCB, 4-ių HCH ir 6-ių DDT suminès koncentracijos ore Lietuvos teritorijoje kito $6,4-127,8 \mathrm{ng} \mathrm{m}^{-3}, 0,017-0,440 \mathrm{ng} \mathrm{m}^{-3}$, $0,088-0,310 \mathrm{ng} \mathrm{m}^{-3}, 0,006-0,360 \mathrm{ng} \mathrm{m}^{-3}$ ribose, o dirvoje 29,5$529,3 \mathrm{ng} \mathrm{g}^{-1}, 0,6-24,0 \mathrm{ng} \mathrm{g}^{-1}, 0,4-1,1 \mathrm{ng} \mathrm{g}^{-1}, 0,3-7,7 \mathrm{ng} \mathrm{g}^{-1}$ ribose. Nustatyta tiesioginè priklausomybè tarp koncentracijų POT atmosferos ore ir dirvoje. Tarp tirtu POT grupiu policikliniu aro- matinių angliavandenilių koncentracijos buvo didžiausios ir atmosferos ore, ir dirvoje. Beveik visų POT didžiausios koncentracijos buvo Vilniaus mieste, o mažiausios - Rūgšteliškio stebèsenos stotyje. Polichlorbifenilų, ypatingai PCB28, koncentracijos buvo didesnès vasarą, esant aukštesnei oro temperatūrai. Skirtingai nuo kitų POT, policiklinių aromatinių angliavandenilių koncentracija ore mažéjo nuo šildymo sezono iki vasaros pradžios. Vidutinès benz(a)pireno koncentracijos atmosferos ore vertès, nustatytos naudojant pasyvius sorbentus, buvo mažesnès už jų vidutines vertes, nustatytas imant oro bandinius mažu filtracijos greičiu. Tai rodo, kad pasyvių sorbentų metodas labiau tinka nustatant dujines negu aerozolines POT koncentracijas. Tokie plataus spektro patvariu organinių teršalų tyrimai gamtinès aplinkos sanduose Lietuvoje atlikti pirmą kartą. 